\title{
Essential Oils of Three Conifer Species from FRIM's Main Campus
}

\author{
Mailina J*, Nor Azah MA, Saidatul Husni S \& Mohammad Faridz ZP \\ Herbal Product Development Programme, Natural Products Division, \\ Forest Research Institute Malaysia (FRIM), 52109 Kepong, Selangor, Malaysia \\ *Corresponding author: mailina@frim.gov.my
}

\begin{abstract}
A study was performed to investigate the volatile constituents of three conifer species (Podocarpus neriifolius, Nageia motleyi and Dacrydium elatum) which were planted in the main campus of Forest Research Institute Malaysia (FRIM). The fresh leaves were extracted by Clavenger hydrodistillation apparatus and the essential oils were analysed by GC and GC/MS analysis. Analyses revealed that the P. neriifolius and N. motleyi oils were rich with sesquiterpenes and have monoterpenes in very trace amount. The major sesquiterpenes of $P$. neriifolius oil were phyllocladene (26.37\%), kaurene $(13.75 \%)$, bicyclogermacrene $(12.14 \%)$ and followed by sandaracopimara-8(14), 15-diene (7.89\%) and $\beta$ caryophyllene $(6.25 \%)$. Meanwhile, the major components of $N$. motleyi oil were bicyclogermacrene (45.85\%), viridiflorene $(12.36 \%)$, globulol $(9.48 \%)$ and germacrene D $(6.15 \%)$. D. elatum oil has mono- and sesquiterpenes as its main components in which $\beta$-caryophyllene $(29.03 \%), \alpha$-pinene $(28.41 \%)$, phyllocladene $(22.89 \%), \alpha$-humulene $(4.27 \%)$ and pimaradiene $(2.61 \%)$ were detected in this oil. The chemical compounds identified are responsible for the aroma of these selected conifer species and showed the potential of conifer plants as a source of aroma chemicals.
\end{abstract}

Keywords: Podocarpaceae, conifer, essential oil, GC and GC/MS analysis

\section{INTRODUCTION}

Forest Research Institute Malaysia (FRIM) has established several arboretums for the conservation and research purposes. One of the arboretum namely Coniferatum, established since 1949 was mainly planted conifer species from various resources. Some of the species planted were from the gymnospermous family, Podocarpaceae. This family is made up of 180 species from 18 genera [1].

Podocarpus is the largest of genera containing about 100 species that are mainly distributed in the tropics and subtropics of the southern hemisphere $[1,2]$. Podocarpus species were used in traditional medicine for human and animal healthcare [3]. Taxol, a significant anticancer agent was isolated from $P$. gracilior. Other uses of Podocarpus species are timber, food, wax, tannin and as ornamental trees [4]. $P$. neriifolius or locally known as Podo bukit are used as ornamental trees, mostly for landscaping. Nagilactone C [5], amentoflavone, podocarpusflavone A, podocarpusflavone $\mathrm{B}$ and isoginkgetin [6] 7,4'dimethylaromadendrin and 7,4'-dimethylaromadendrin 5-glucoside [7] were isolated from P. neriifolius.

Nageia motleyi or podo kebal musang is a big tree up to $50 \mathrm{~m}$ tall. This species can be found in Thailand, Sumatra, Peninsular Malaysia and Borneo. It is important timber trees as valuable construction wood [2].

Dacrydium elatum is an evergreen coniferous tree. The distribution is in China, Thailand, Indo-China, Malaysia and Philippines. In Malaysia, the vernacular name for this species is ekor kuda. It can be found in Kedah, Penang, Perak, Selangor, Terengganu, Pahang and Johor. It is an ornamental plant and recorded as the main source of sempilor wood in Southeast Asia [2].

To the best of our knowledge, there is no previous report on chemical constituents of the oils from these selected three species. 


\section{EXPERIMENTAL}

\section{Plant materials and essential oil preparation}

The fresh leaf samples of Podocarpus neriifolius, Nageia motleyi and Dacrydium elatum were collected at Field 13 (Coniferatum) in FRIM's main campus. All the samples were processed immediately the moment it arrives at the lab. They were cut into small pieces before weighed and subjected to hydrodistillation technique for six hours using Clavenger-type apparatus. The oils were collected and isolated from their hydrosol using anhydrous sodium sulphate. The pure oils were kept in fridge prior further analysis.

\section{GC analysis}

Analyses of the oils were conducted by Gas Chromatography (GC) using model Shimadzu GC-2010 Plus capillary chromatograph which was equipped with a flame ionization detector (FID) and using split/splitless mode injection technique, under the following conditions: carrier gas helium; similar temperature for injector and detector at $250^{\circ} \mathrm{C}$. This chromatograph is using a non-polar capillary column BP-5 (30m by $0.25 \mathrm{~mm}$, film thickness $0.25 \mu \mathrm{m}$ ). Operating conditions are as follows; initial oven temperature, $60^{\circ} \mathrm{C}$ for $10 \mathrm{~min}$, up to $230^{\circ} \mathrm{C}$ at $3^{\circ} \mathrm{C} / \mathrm{min}$ and then $230^{\circ} \mathrm{C}$ for $10 \mathrm{~min}$.

\section{GC/MS analysis}

Gas Chromatography/Mass Spectrometry (GC/MS) analyses were conducted on Agilent Technologies GCMS 7890A/5975C Series MSD with similar condition as described in GC programs using HP-5MS column $(30 \mathrm{~m}$ by $0.25 \mathrm{~mm}$, film thickness $0.25 \mu \mathrm{m})$. The chemical constituents were identified by comparison of retention times and calculated kovat's indices with reference [8] and literature values and matching their mass spectra with database library (HPCH2205.L; Wiley7Nist05.L; NIST05a.L).

\section{RESULTS AND DISCUSSION}

The leaf essential oils of Podocarpus neriifolius, Nageia motleyi and Dacrydium elatum were extracted separately by hydrodistillation Clavenger-apparatus for 6 hours. The oil yield of D. elatum gave higher percentage at $0.39 \% \mathrm{v} / \mathrm{w}$ and followed by P. neriifolius $(0.02 \% \mathrm{v} / \mathrm{w})$ and $N$. motleyi $(0.01 \% \mathrm{v} / \mathrm{w})$. All three samples were subjected to GC and GC/MS analysis, which allowed of 20 (88.58\%), 15 (84.95\%) and 29 (98.71\%) compounds identified in P. neriifolius, N. motleyi and D. elatum, respectively (Table 1).

Table 1 The chemical constituents of Podocarpus neriifolius, Nageia motleyi and Dacrydium elatum leaf oils

\begin{tabular}{clcccc}
\hline & & Chemical name & Retention & \multicolumn{3}{c}{ \% Area } \\
\cline { 5 - 6 } & & index & PN & NM & DE \\
\hline 1 & $\alpha$-Pinene & 934 & $\mathrm{t}$ & $\mathrm{t}$ & 28.41 \\
2 & Sabinene & 970 & - & - & 1.00 \\
3 & $\beta$-Pinene & 976 & - & - & 1.77 \\
4 & Myrcene & 989 & - & - & 1.37 \\
5 & $\gamma$-Terpinene & 1063 & - & - & $\mathrm{t}$ \\
6 & Terpinolene & 1087 & - & - & 0.08 \\
7 & Terpinen-4-ol & 1172 & - & - & 0.05 \\
& & & & & continue... \\
8 & $\alpha$-Terpineol & 1187 & - & - & 0.23 \\
9 & $\alpha$-Cubebene & 1351 & 1.80 & - & 0.06 \\
10 & $\alpha$-Copaene & 1377 & 1.40 & - & 0.08
\end{tabular}




\begin{tabular}{|c|c|c|c|c|c|}
\hline 11 & $\beta$-Cubebene & 1390 & 0.97 & - & - \\
\hline 12 & $\beta$-Elemene & 1393 & - & 1.46 & 1.01 \\
\hline 13 & Siberene & 1400 & $\mathrm{t}$ & - & - \\
\hline 14 & (Z)-Caryophyllene & 1405 & - & - & 0.38 \\
\hline 15 & $\alpha$-Gurjunene & 1410 & - & $\mathrm{t}$ & - \\
\hline 16 & $\beta$-Caryophyllene & 1419 & 6.25 & 0.98 & 29.03 \\
\hline 17 & Aromadendrene & 1441 & 0.76 & 1.06 & $\mathrm{t}$ \\
\hline 18 & $\alpha$-Humulene & 1455 & 1.02 & - & 4.27 \\
\hline 19 & trans-Cadina-1(6),4-diene & 1476 & - & 1.89 & - \\
\hline 20 & Germacrene D & 1480 & 4.54 & 6.15 & 0.34 \\
\hline 21 & $\beta$-Selinene & 1483 & - & - & 0.25 \\
\hline 22 & Viridiflorene & 1495 & 1.60 & 12.36 & - \\
\hline 23 & Bicyclogermacrene & 1500 & 12.14 & 45.85 & 1.56 \\
\hline 24 & Premnaspirodiene & 1506 & - & - & 0.12 \\
\hline 25 & $\delta$-Amorphene & 1511 & 2.24 & - & 0.10 \\
\hline 26 & $\gamma$-Cadinene & 1513 & - & 0.65 & - \\
\hline 27 & Spathulenol & 1577 & 2.10 & - & - \\
\hline 28 & Caryophyllene oxide & 1582 & - & - & 0.54 \\
\hline 29 & Globulol & 1583 & - & 9.48 & 0.05 \\
\hline 30 & Pogostol & 1651 & - & 2.07 & - \\
\hline 31 & Selin-11-en-4-alpha-ol & 1652 & - & - & 0.10 \\
\hline 32 & $\alpha$-Cadinol & 1653 & $\mathrm{t}$ & 1.91 & 0.14 \\
\hline 33 & Rimuene & 1896 & - & - & 0.46 \\
\hline 34 & Beyerene & 1925 & 2.79 & - & - \\
\hline 35 & Isohibaene & 1928 & - & - & 0.46 \\
\hline 36 & Pimaradiene & 1943 & 1.80 & 1.09 & 2.61 \\
\hline 37 & $\begin{array}{l}\text { Sandaracopimara-8(14),15- } \\
\text { diene }\end{array}$ & 1962 & 7.89 & - & 1.17 \\
\hline 38 & 13-epi-Manool oxide & 2010 & 1.16 & - & - \\
\hline 39 & Phyllocladene & 2013 & 26.37 & - & 22.89 \\
\hline 40 & Kaurene & 2035 & 13.75 & - & - \\
\hline 41 & Abietatriene & 2055 & - & $\mathrm{t}$ & 0.01 \\
\hline 42 & Abietadiene & 2083 & - & - & $\mathrm{T}$ \\
\hline 43 & Sandaracopimarinal & 2186 & - & - & \\
\hline
\end{tabular}

Note: $\mathrm{t}=$ trace; $\mathrm{PN}=$ Podocarpus neriifolius; $\mathrm{NM=Nageia}$ motleyi $;$ Dacrydium elatum

$P$. neriifolius and $N$. motleyi gave leaf oils in which the majority of the oils were accounted by sesquiterpene and have less amount of monoterpene. Meanwhile, the D. elatum produced a leaf oil that contained mixtures of monoterpene and sesquiterpene as the main components (Figure 1). There are seven compounds detected in all of the three oils which were $\alpha$-pinene, $\beta$-caryophyllene, aromadendrene, germacrene $\mathrm{D}$, bicyclogermacrene, $\alpha$-cadinol and pimaradiene. 


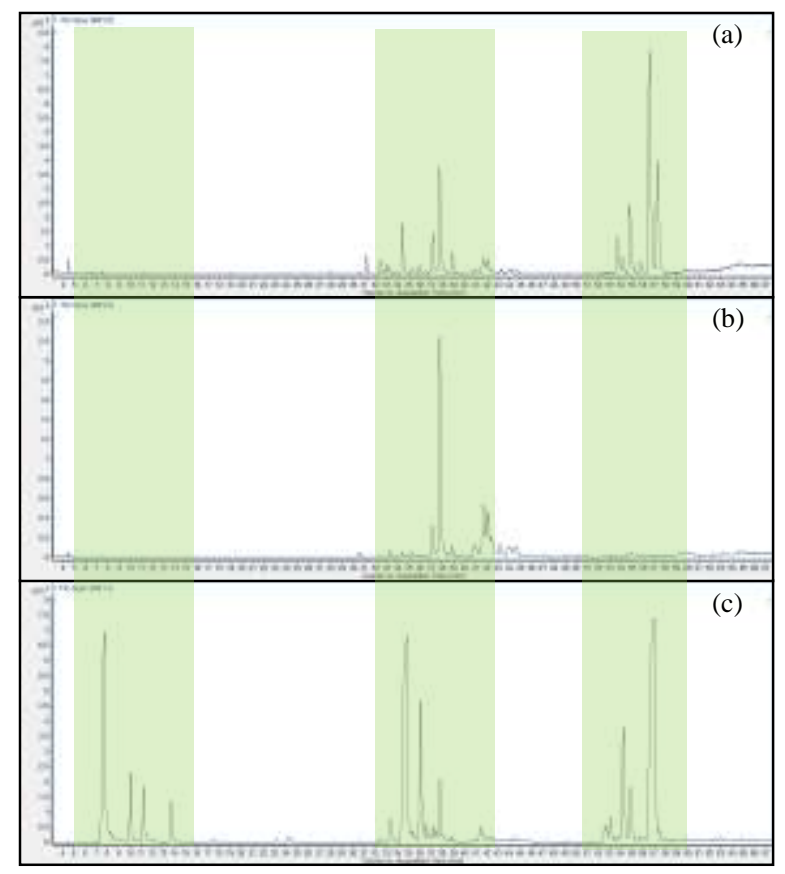

Figure 1 The total ion chromatogram for P. neriifolius (a), N. motleyi (b) and D. elatum (c) leaf oil

The major components of $P$. neriifolius were phyllocladene $(26.37 \%)$, kaurene $(13.75 \%)$ and bicyclogermacrene (12.14\%). The other appreciable components were sandaracopimara-8(14), 15-diene $(7.89 \%)$ and $\beta$-caryophyllene $(6.25 \%)$. The remaining components detected were present in lower percentage (below than 5\%). Previously, no report on the present of phyllocladene in other Podocarpus oils [1]. $\alpha$-Pinene (9.3\%) was detected as the major components of $P$. totara [9]. Bicyclogermacrene (45.85\%), viridiflorene (12.36\%), globulol $(9.48 \%)$, germacrene D (6.15\%) were identified as the major components in $N$. motleyi oil. Only one monoterpene compound detected which was $\alpha$-pinene and it was presented in trace amount. The $D$. elatum leaf oil contained approximately $30 \%$ monoterpenes in which $\alpha$-pinene $(28.41 \%)$ was identified as one of the major components among them. The other monoterpenes were $\beta$ pinene, myrcene, sabinene, terpinolene, terpinen-4-ol and $\alpha$-terpineol in appreciable percentage. The principal sesquiterpenes were $\beta$-caryophyllene (29.03\%) and phyllocladene $(22.89 \%)$.

\section{CONCLUSION}

The chemical constituents from these coniferous plants represent a valuable chemotaxonomic tool for the identification of species. The oils as well as extracts could further be studied for investigation of their biological potential.

\section{ACKNOWLEDGEMENT}

We would like to express heartfelt thanks to Mr. Kamarudin Salleh for technical assistance and encouragements during the work. The budget was supported by FRIM funding (RPP-113-PPH-03). 


\section{REFERENCES}

[1] Farjon, A. (2010). Podocarpaceae. Flora of Peninsular Malaysia, Malayan Forest Records 49, Series II: Seed Plant 1: 171-195.

[2] Joseph, J.B. and Robert, J.G. (2004). Chemistry of the Australian Gymnosperms. Part 6. Leaf Oils of the Australian Species of Genus Podocarpus. Journal of Essential Oil Research 16: 342-346.

[3] Halima S.A., Luc V., Jeffrey F.F \& Johannes V.S. (2012). Mutagenicity, antimutagenicity and cytotoxicity evaluation of South African Podocarpus species. Journal of Ethnopharmacology 139: 728-738.

[4] Abdillahi H.S. Stafford G.I., Finnie J.F. \& Van Staden J. (2010). Ethnobotany, phytochemistry and pharmacology of Podocarpus sensu latissimo (s.1.). South African Journal of Botany 76:1-24.

[5] Shrestha K., Banskota A.H., Kodata S., Shrivastava S.P., Strobel G. \& Gewali M.B. (2001). An antiproliferative norditerpene dilactone, Nagilactone C, from Podocarpus neriifolius. Phytomedicine 8(6): 489-491.

[6] Syed Haider M.R., Wasiur R., Masayoshi O. \& Nobusuke K. (1974). Biflavones from Podocarpus neriifolius. Phytochemistry 13: 1990.

[7] Syed Haider M.R. \& Wasiur R. (1974). 7, 4'-Dimethylaromadendrin and Its 5-Glucoside from Podocarpus neriifolius. Phytochemistry 13: 2879.

[8] Adam, R.P. (2012). Identification of Essential oil Components by Gas Chromatography/Mass spectrometry, $4^{\text {th }}$ Edition. Allured Business Media: Carol Stream, Illinois

[9] Franich, R.A. and Cambie R.C. (1999). Essential Oil Constituents of Podocarpus totara Leaves. Journal Of Essential Oil Research 11: 507-510. 